\title{
Pendidikan dalam Perspektif Hadis
}

\author{
Hasbi Siddik \\ Sekolah Tinggi Agama Islam Negeri (STAIN) Sorong, Papua Barat \\ jalanbima762@gmail.com
}

Abstract: This paper will explore education in the perspective of Hadith, both the meaning, the nature, and the practice of education, as well as its urgency. In the books of Hadis (al-kutub al-tisah) there are many themes that talk about education. In the books it is mentioned a lot of terms tarbiyah, ta'lim, ta'dib, and other terms associated with it such as 'ilm, al-aql, al-fikr, al-hikmah, and so on. The number of Hadis proves that the Prophet during his life did pay special attention to the issue of education. The search for an educational theme in the Hadis is a thematic study method (syarh al-mawdhui). The results of this study found that there are at least five themes in the Hadis on education: 1) the primacy of education (educating children); 2) the urgency of teaching science (in education); 3) the reward obtained for the learners; 4) fitrah (for children) to learn in education; 5) education from an early age (the obligation of parents to educate their children in worship or praying).

Keywords: Islamic Education, Education in Perspective of Hadis, and the Importance of Education. 


\section{Pendahuluan}

Hadis Nabi Saw. adalah sumber ajaran Islam setelah al-Qur'an. Dalam berbagai ayat al-Qur'an disebutkan bahwa kedudukan Muhammad Saw sebagai Nabi dan Rasul Allah mesti diikuti petunjuk-petunjuknya. ${ }^{1} \mathrm{Hal}$ tersebut juga mengindikasikan bahwa Hadis-Hadis Nabi Saw., di samping sumber ajaran Islam, juga merupakan bayan li al-Qur'an (penjelas mengenai isi al-Qur'an). Hadis-Hadis Nabi, telah termaktub dalam berbagai kitab Hadis ${ }^{2}$ dan telah beredar di kalangan masyarakat luas. Dalam kitab-kitab Hadis tersebut ditemukan banyak tema yang membicarakan tentang pendidikan. Fakta ini, juga membuktikan bahwa Hadis-Hadis tentang pendidikan yang terdapat dalam kitab-kitab Hadis sangat banyak jumlahnya. Bahkan, Hadis-Hadis tentang pendidikan tersebut, sangat luas pembahasannya dalam kitab-kitab syarah Hadis.

Tema pendidikan dalam perspektif Hadis dapat ditelusuri dalam Mu'jam al-Mufahras li Alfaz al-Hadis al-Nabawiyah melalui lafal tarbiyah, ta'lim, ta'dib, dan lafal-lafal lain yang terkait dengannya, misalnya 'ilmu, al-aql, al-fikr, dan al-hikmah. Lafal ilmu telah ditemukan informasi dari $M u^{\prime} j a m$ kurang-lebih 822 Hadis. ${ }^{3}$ Lebih dari itu, tema pendidikan dapat pula dianalisis dari lafal fitrah. Kesemua lafal ini, di samping terdapat dalam Mu'jam, juga terdapat dalam Miftah Kunus al-Sunnah, dan di era sekarang dapat pula ditelusuri melalui CD Rom Hadis dalam program komputerisasi.

1 Ayat-ayat yang berkenaan dengan hal tersebut di atas adalah antara lain Q.S. al-Nisa ([4]: 80); Q.S. Ali Imran (3]: 32); dan QS. al-Hasyr ([59]: 7).

2 Misalnya Shahih al-Bukhariy, Shahih Muslim, Sunan Abu Dawud, Sunan al-Turmuziy, Sunan al-Nasa'i, Sunan al-Darimi, Sunan Ibn Majah, Kitab Muwaththa' Malik, dan Musnad Ahmad ibn Hanbal. Kesembilan kitab Hadis ini disebut al-Kutub al-Tis'ah. Di samping itu, adapula sejumlah kitab Hadis yang juga cukup dikenal di masyarakat, namun kitab-kitab dimaksud tidak banyak beredar. Sebagian dari kitabkitab itu dapat disebutkan, misalnya Musnad al-Humaydi, Musnad Abu 'Awanah, al-Mustadrak li al-Hakim, dan al-Sunan al-Kubra li al-Bayhaqy, serta yang lainnya.

3 A. J. Wensinck, Concordance et Indices De Ela Tradition Musulmanne, terj. Muhammad Fu'ad 'Abd. al-Baqy (al-Mu'jam al-Mufahras li Alfaz al-Hadits alNabawiyah), jilid IV (Leiden: E.J.Brill, 1936), 312-338. 
Kaitannya dengan tema pendidikan, maka Hadis-Hadis yang tidak menggunakan lafal tarbiyah, ta'lim, ta'dib, dan lafal-lafal lain yang terkait dengannya, tetapi Hadis tersebut memiliki kaitan dengan urgensi pendidikan, dapat pula dikategorikan sebagai Hadis tentang pendidikan secara tematik. Misalnya saja, Hadis tentang perintah untuk mendidik anak menjalankan shalat sejak umur tujuh tahun. Banyaknya HadisHadis Nabi Saw. yang terkait dengan pendidikan, adalah sesuatu yang wajar karena harus diakui bahwa dalam sejarah Nabi Saw. diketahui beliau dalam setiap harinya senantiasa mendidik dan mengajar sahabatsahabatnya. Sistem pendidikan dan pengajaran tersebut disampaikannya secara formal melalui forum majelis ilmu. Di samping itu, beliau juga menyampaikan pengajaran secara non formal melalui pertemuan-pertemuan yang tidak resmi.

Dapatlah dipahami bahwa selama hidupnya, Nabi Saw. telah memberi perhatian khusus terhadap masalah pendidikan. Respons dan stimulus Nabi Saw. terhadap masalah pendidikan ini, paling tidak dapat dilihat dari Hadis-Hadisnya. Karena itu, dapat dikatakan bahwa ajaran Islam amat peduli terhadap masalah pendidikan. Kenyataan tersebut berimplikasi pada pentingnya penelitian terhadap Hadis-Hadis ${ }^{4}$ tentang pendidikan yang terdapat dalam berbagai kitab Hadis. Lebih penting lagi, bila Hadis-Hadis tersebut dielaborasi dengan metode tematik (syarh al-mawdhui) ${ }^{5}$ dengan tetap memperhatikan kegiatan-kegiatan lainnya, seperti kegiatan takhrij al-Hadis, naqd al-Hadis dan fiqh al-Hadis.

4 H. M. Syuhudi Ismail menyatakan bahwa latar belakang pentingnya penelitian Hadis adalah (1) Hadis Nabi sebagai salah satu sumber ajaran Islam; (2) tidak seluruh Hadis tertulis pada zaman Nabi; (3) telah timbul berbagai pemalsuan Hadis; (4) proses penghimpunan Hadis memakan waktu yang lama; (5) jumlah kitab Hadis yang banyak dengan penyusunan yang beragam; (6) telah terjadi periwayatan secara makna. Uraian lebih lanjut, lihat M. Syuhudi Ismail, Kaedah Kesahihan Sanad Hadis (Jakarta: Bulan Bintang, 1988), 75.

5 Metode tematik (syarh al-mawdhu'i) yang dimaksud di sini adalah membahas Hadis-Hadis yang berkenaan dengan suatu masalah dalam ajaran Islam, misalnya masalah akidah, hukum-hukum (ahkam), akhlak, dan lain-lain. "Kontrak Perkuliahan Hadis Mawdhu'i," Semester I Program S-3 (Doktor) Tahun Akademik 2006-2007. PPS IAIN Alauddin Makassar, 2. 


\section{Pengertian Pendidikan}

Kata pendidikan pada awalnya berasal dari bahasa Yunani, paedagogie yang terdiri atas dua kata, paes dan ago. ${ }^{6}$ Kata paes berarti anak, dan kata ago berarti aku membimbing. ${ }^{7}$ Dengan demikian, pendidikan secara etimologis selalu dihubungkan dengan kegiatan bimbingan terutama kepada anak, karena anak yang menjadi objek didikan. Selanjutnya, kata pendidikan dalam bahasa Inggris disebut dengan education ${ }^{8}$ dan dalam bahasa Arab ditemukan penyebutannya dalam tiga kata, yakni al-tarbiyah, al-ta'lìm, dan al-ta'dīb yang secara etimologis kesemuanya bisa berarti bimbingan dan pengarahan. Namun demikian, para pakar pendidikan mempunyai kecenderungan yang berbeda dalam hal penggunaan ketiga kata tersebut. ${ }^{9}$ Kata al-tarbiyah dalam Lisān al-Arab, berakar dari tiga kata, yakni raba-yarbu (bertambah, bertumbuh); rabiya-yarba (menjadi besar), dan rabba-yarubbu (memperbaiki). ${ }^{10}$ Pertama, menunjukkan bahwa hakikat pendidikan adalah proses pertumbuhan peserta didik; kedua, pendidikan mengandung misi untuk membesarkan jiwa dan memperluas wawasan seseorang; ketiga, pendidikan adalah memelihara, dan atau menjaga peserta didik. Mengenai kata al-ta'lim menurut Abd. al-Fattah, adalah lebih universal dibandingkan dengan al-tarbiyah dengan alasan bahwa al-ta'lim berhubungan dengan pemberian bekal

${ }^{6}$ Kata dasar pendidikan adalah didik yang didahului awalan "pe" dan akhiran "an", yang mengandung arti perbuatan, hal, cara dan sebagainya. Bisa juga berarti memelihara dan memberi latihan (ajaran, tuntunan, pimpinan) mengenai akhlak dan kecerdasan pikiran. Departemen Pendidikan dan Kebudayaan, Kamus Besar Bahasa Indonesia, Edisi III, Cet. II (Jakarta: Balai Pustaka, 2002), 263.

7 Batasan di atas, dikutip dari Abu Ahmadi, Ilmu Pendidikan, Cet.I (Jakarta: Rineka Cipta, 1991), 69.

8 John M. Echols dan Hassan Shadily, Kamus Inggris-Indonesia (Jakarta: Gramedia, 1981), 81 .

9 Sepanjang pengetahuan penulis, kata tarbiyah juga digunakan oleh Abd. al-Rahmān al-Nahlawi; kata ta'lìm digunakan oleh Abd. al-Fattah Jalāl; sedangkan kata ta'dìb digunakan oleh Naquib al-Attās.

${ }^{10}$ Jamāl al-Dīn Ibn Manzūr, Lisān al-Arab, jilid I (Mesir: Dār al-Mishriyyah, t.t.), 384 dan 389. Luwis Ma'lūf, al-Munjid fì al-Lugah wa A'lām, Cet. XXVII (Beirūt: Dār al-Masyriq, 1997), 243. 
pengetahuan. Pengetahuan ini dalam Islam dinilai sesuatu yang memiliki kedudukan yang sangat tinggi. ${ }^{11}$ Selain itu, al-Attās justru menyatakan bahwa al-tarbiyah terlalu luas pengertiannya, tidak hanya tertuju pada pendidikan manusia, tetapi juga mencakup pendidikan untuk hewan sehingga dia lebih memilih penggunaan kata al-ta'dì $b$ karena kata ini menurutnya, terbatas pada manusia. ${ }^{12}$

Berkaitan dengan uraian-uraian yang telah dikemukakan, dan dengan merujuk pada makna dasar term-term pendidikan tersebut, penulis merumuskan bahwa kata al-ta'dīb lebih mengacu pada aspek pendidikan moralitas (adab); sementara kata al-ta'lim lebih mengacu pada aspek intelektual (pengetahuan); sedangkan kata tarbiyah, lebih mengacu pada pengertian bimbingan, pemeliharaan, arahan, penjagaan, dan pembentukan kepribadian. Karena itu, term yang terakhir ini, kelihatannya menunjuk pada arti yang lebih luas, karena di samping mencakup ilmu pengetahuan dan adab, juga mencakup aspek-aspek lain, yakni pewarisan peradaban, sebagaimana yang dikatakan Ahmad Fu'ad al-Ahwaniy. ${ }^{13}$

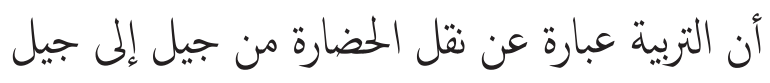

Pada dasarnya, istilah al-tarbiyah mengandung makna pewarisan peradaban dari generasi ke generasi. Lebih lanjut, Muhammad al-Abrāsy menyatakan bahwa al-tarbiyah mengandung makna kemajuan yang terus menerus menjadikan seseorang dapat hidup dengan berilmu pengetahuan berakhlak mulia, mempunyai jasmani yang sehat, dan akal cerdas. ${ }^{14}$ Dengan demikian, kata tarbiyah lebih cocok digunakan dalam mengkonotasikan pendidikan menurut ajaran Islam.

${ }^{11}$ Abd. al-Fattāh Jalāl, Min U Uiūl al-Tarbawiy fī al-Islām (Kairo: Markas al-Duwali li al-Ta’lïm, 1988), 17.

${ }^{12}$ Muhammad Naquib al-Attās, Aims and Objective of Islamic Education (Jeddah: King Abd. al-Azīz, 199), 52.

${ }^{13}$ Ahmad Fu'ad al-Ahwāniy, al-Tarbiyah fìl Islam (Mesir: Dār al-Ma’arif, t.t), 19.

${ }^{14}$ Muhammad Athiyah al-Abrāsy, Rūh al-Tarbiyah wa al-Ta'līm (t.t.: Isā al-Bābī al-Halab, t.t), 14. 
Masih mengenai pengertian pendidikan, dalam hal ini batasan istilah tarbiyah, al-Nahlawi merumuskan bahwa istilah tersebut sekurangkurangnya mengandung empat konsep dasar, yakni:

1. Pendidikan merupakan kegiatan yang betul-betul memiliki target, tujuan, dan sasaran.

2. Pendidik yang sejati dan mutlak adalah Allah Swt. Dialah Pencipta fitrah, Pemberi bakat, Pembuat berbagai Sunnah perkembangan, peningkatan dan interaksi fitrah, sebagaimana Dia pun mensyariatkan aturan guna mewujudkan kesempurnaan, kemaslahatan dan kebahagiaan manusia.

3. Pendidikan menuntut terwujudnya program berjenjang, peningkatan kegiatan, dan pengajaran selaras dengan urutan juga sistematika menanjak yang membawa anak didik dari suatu perkembangan ke perkembangan lainnya.

4. Peran seorang pendidik harus sesuai dengan tujuan Allah Swt menciptakannya. Artinya, pendidik harus mampu mengikuti syariat agama Allah. ${ }^{15}$

Berkenaan dengan itulah, maka pendidikan (tarbiyah) yang dimaksud dalam tulisan ini, adalah proses pembentukan individu berdasarkan ajaran-ajaran Islam. Melalui proses pendidikan itu, individu dibentuk agar dapat mencapai derajat yang tinggi dan sempurnah (insan kamil), agar mampu melaksanakan fungsinya sebagai 'abdullāh dan tugasnya sebagai khalîfatullāh dengan sebaik mungkin. Dari batasan pengertian tentang pendidikan itu, melahirkan berbagai interpretasi yang termuat di dalamnya. Yakni, adanya unsur-unsur edukatif yang sekaligus sebagai konsep bahwa pendidikan itu merupakan suatu usaha, usaha itu dilakukan secara sadar, usaha itu dilakukan oleh orang-orang yang mempunyai tanggung jawab kepada masa depan anak, usaha itu mempunyai dasar dan tujuan tertentu, usaha itu perlu dilaksanakan secara teratur

\footnotetext{
${ }^{15}$ Abdurrahman al-Nahlawy, Prinsip-Prinsip dan Metode Pendidikan Islam (Usul al-Tarbiyah al-Islamiyah wa Asâlibuha) terj. Herry Noor Ali, Cet. II (Bandung: IKAPI, 1992), 21.
} 
dan sistimatis, usaha itu memerlukan alat-alat yang digunakan.

\section{Klasifikasi Hadis-Hadis Tentang Pendidikan}

Dalam istilah ilmu Hadis, takhrij adalah kegiatan pencarian hadis sampai menemukannya dalam berbagai kitab Hadis yang disusun langsung oleh mukharrij-nya. Dalam kitab-kitab tersebut disebutkan Hadis secara lengkap dari segi sanad dan matan. ${ }^{16}$ Arifuddin Ahmad dan pakar Hadis lainnya menyatakan bahwa takhrij al-Hadis dapat dilakukan dengan metode bi alfaz dan bi al-mawdu'i. Takhrij yang disebutkan pertama berdasarkan lafal dan takhrij yang disebutkan kedua berdasarkan topik masalah. ${ }^{17}$ Karena kajian ini menggunakan metode tematik, maka takhrij dilakukan adalah takhrij bi al-mawdhu'i. Namun untuk Hadis tertentu, tetap digunakan takhrij dengan metode bi alfaz. Fasilitas takhrij yang penulis digunakan adalah kitab Mu'jam dan CD-Rom (Compact Disc-Read Only Memory) Hadis melalui program komputer.

Dengan merujuk pada makna yang terkandung dalam istilah tarbiyah, maka kitab Mu'jam dan CD-Rom Hadis memberikan data-data takhrīj Hadis tentang pendidikan sebagai berikut:

1. Takhrīj Hadis tentang keutamaan mendidik anak, pada kitab Mu'jam Mufahras ditemukan informasi sebagai berikut:

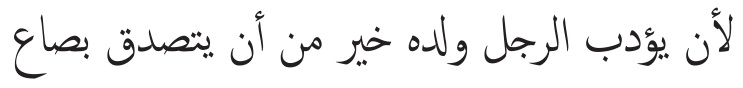

2. Takhrij Hadis tentang urgensi mengajarkan ilmu melalui pendidikan, pada Mu'jam Miftah Kunuz al-Sunnah, ditemukan

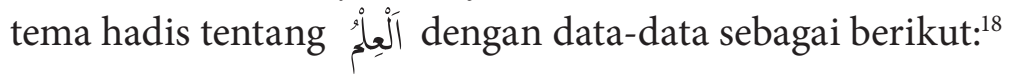

\footnotetext{
${ }^{16}$ M. Syuhudi Ismail, Metodologi Penelitian Hadis. Cet. I (Jakarta: Bulan Bintang, 1992), 43.

${ }^{17}$ Uraian lebih lanjut, lihat H. Arifuddin Ahmad, Prof. Dr. H.M.Syuhudi Ismail: Paradigma Baru Memahami Hadis Nabi. Cet. I (Jakarta: Intimedia dan Insan Cemerlang, 2003), 179-180.

${ }^{18}$ A.John Wensinck, A Handbook of Early Muhammadan (Miftah Kunuz al-Sunnah), terj. Muhammad Fu'ad 'Abd. al-Baqy (Beirut: Dar Ihya al-Turats al-Arabiy, 1422 H),
} 


$$
\text { مثل ما بعنى الله به من الهدى والعلم كمل الغيث الكثير - }
$$

Untuk kelengkapan data-data Hadis yang bertemakan ilmu, maka penulis juga menggunakan alat bantu CD-Rom. Dengan upaya seperti ini, penulis menemukan informasi yang sejalan dengan data-data Hadis yang bersumber dari Miftah Kunuz alSunnah, yakni:

\begin{tabular}{|c|c|c|c|c|}
\hline طرف الحلديث & 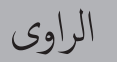 & حديث & المصدر & 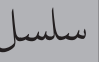 \\
\hline 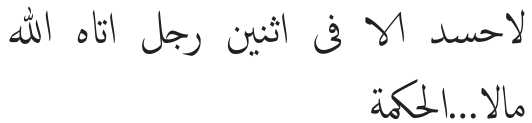 & عبدالله & 71 & & 1 \\
\hline مثل ما بعثى الله به من الهلى والعلم... & عبدالله & 77 & ذاري & 2 \\
\hline لاحسد الا لا ف اثنين رجل اتاه الله & عبدالله & 1352 & & 3 \\
\hline إن مثل ما بعثى الله به من الهـى & عبدالله & 4232 & & 4 \\
\hline
\end{tabular}

Sumber Data: CD-Rom, al-Kutub al-Tis'ah.

3. Takhrïj Hadis tentang balasan yang diperoleh bagi penuntut ilmu dalam pendidikan, juga ditemukan dalam petunjuk Miftah Kunus al-Sunnah dan data CD-Rom sebagaimana dalam poin nomor 2 di atas. Hal ini disebabkan Hadis yang dimaksud di dalamnya terdapat kata al-'ilmu dan al-hikmah.

4. Takhrìj Hadis tentang konsep fitrah dalam dunia pendidikan, pada kitab Mu'jam Mufajras ditemukan informasi sebagai berikut:

$$
\text { ما من مولود (يولد) إلا يولد على الفطرة ... }
$$


Selanjutnya, pada CD-Rom Hadis juga ditemukan informasi bahwa di samping Hadis tersebut diriwayatkan oleh Bukhari, Muslim, dan Ahmad, juga diriwayatkan oleh Abu Dawud dalam kitab al-Sunnah, Hadis ke-4091.

5. Takhrīj Hadis tentang pendidikan shalat bagi anak sejak umur tujuh tahun, ditemukan data yang sama dalam $M u^{\prime}$ jam bahwa Hadis tersebut dalam Sunan al-Turmuzi kitab al-Shalat Hadis ke-272, dan Sunan al-Darimi, kitab al-Shalat Hadis ke-1395.

Dari proses takhrij yang telah dilakukan, maka Hadis-Hadis tentang pendidikan dapat diklasifikasi lebih lanjut berdasarkan kandungan wurud-nya. Klasifikasi Hadis yang dimaksudkan diurut berdasarkan tema-tema Hadis yang menjadi objek pembahasan sebagai berikut:

1. Hadis tentang keutamaan mendidik anak, susunan sanad dan matan-nya:

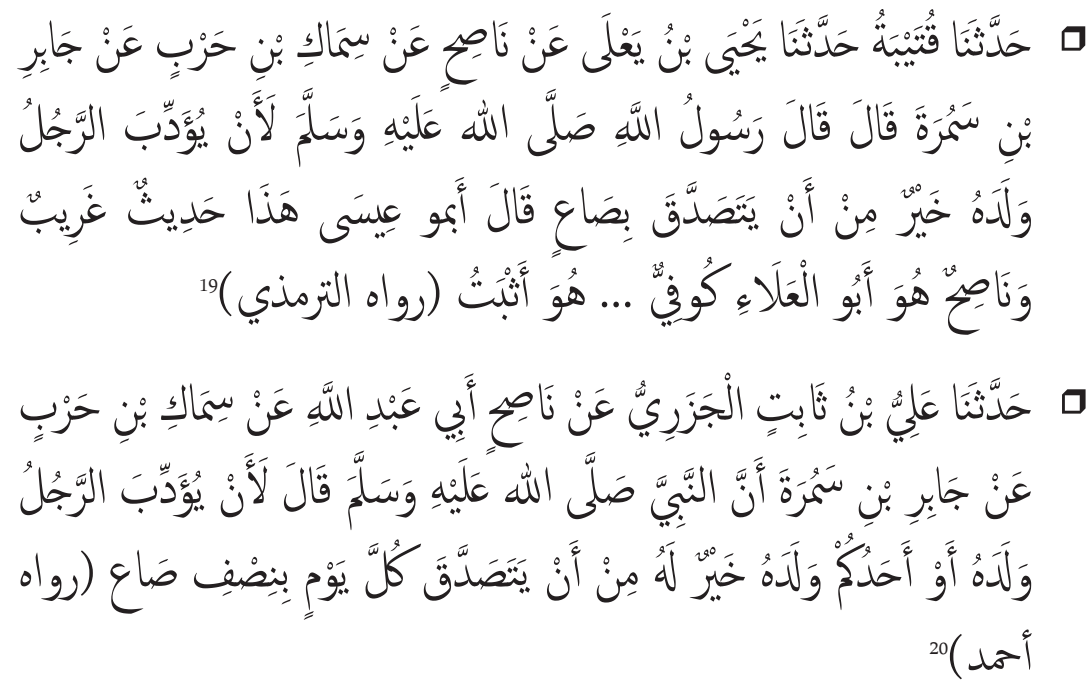

${ }^{19}$ Abu Isa Muhammad bin Isa al-Turmuzi, Sunan al-Turmuzi, dalam al-Kutub al-Tis'ah, Hadis ke-1874. CD-Rom Hadis.

${ }^{20}$ Abu Abdullah Ahmad bin Hanbal, Musnad Ahmad bin Hanbal, dalam Musnad al-Bashriyyin, Hadis ke-19995. CD-Rom Hadis. 


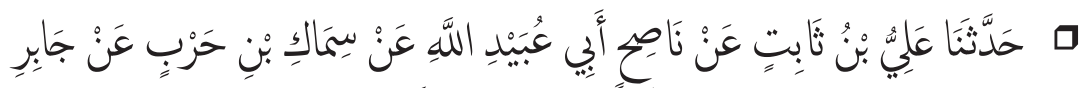

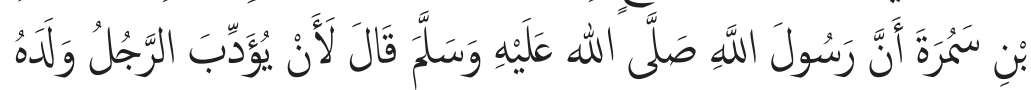

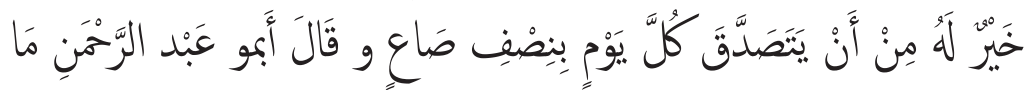

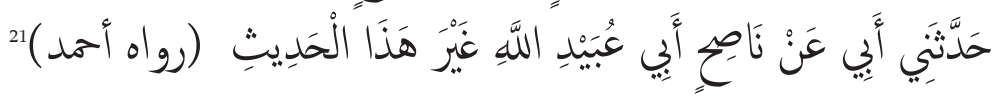

2. Hadis tentang urgensi mengajarkan ilmu melalui pendidikan, susunan sanad dan matan-nya sebagai berikut:

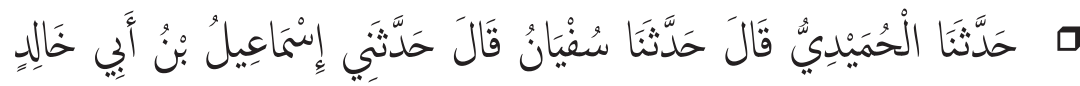

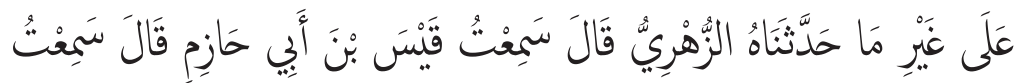

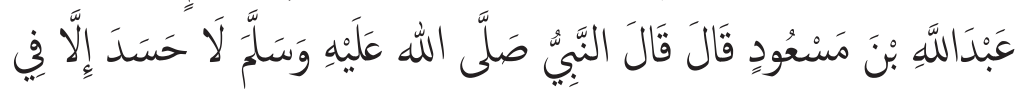

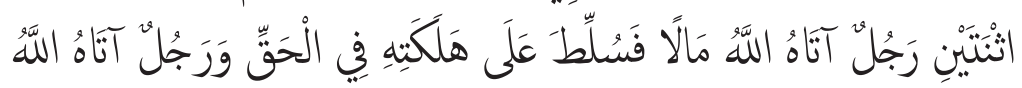

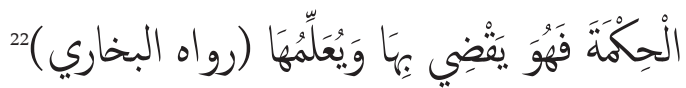

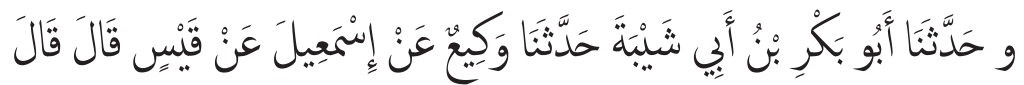

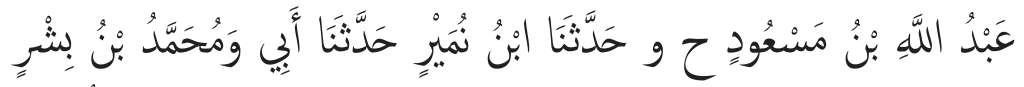

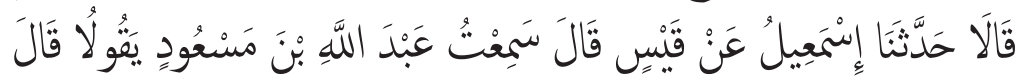

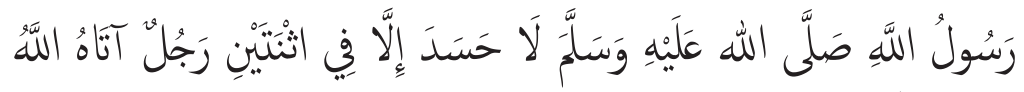

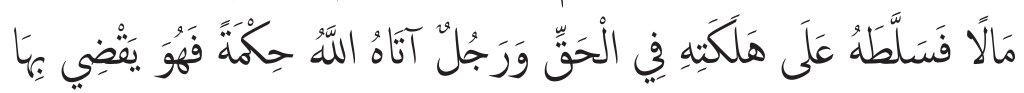

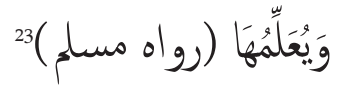

${ }^{21}$ Ibid., Hadis ke-20065.

${ }^{22}$ Abu 'Abdullah Muhammad bin Isma'il bin Ibrihim Ibn al-Mugirah bin Bardizbat al-Bukhari, Shahih, Juz I (t.tt.: Dar Matba' al-Syabi, t.t), 28; lihat juga, kitab al-'Ilmu, Hadis ke-71. CD-Rom Hadis.

${ }^{23} \mathrm{Abu}$ al-Hasan Muslim bin al-Hajjaj bin Muslim al-Qusyairy, Shahih Muslim, Juz I (Bandung: Maktabah Dahlan, t.t), 799; lihat juga kitab al-'Ilmu, Hadis ke-1352. CD-Rom Hadis. 
3. Hadis tentang balasan yang diperoleh bagi penuntut ilmu dalam pendidikan, susunan I dan matan-nya sebagai berikut:

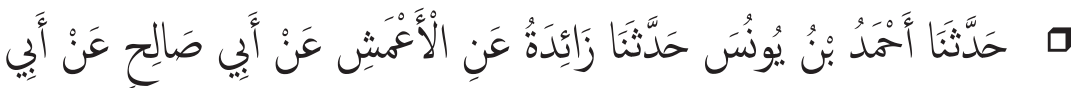

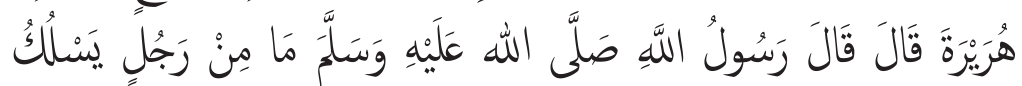

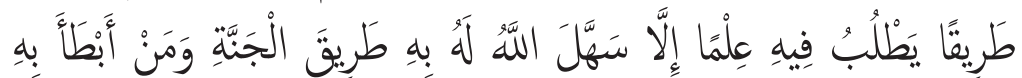

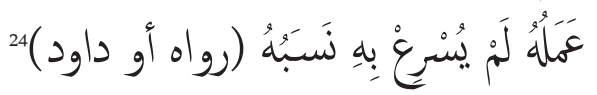

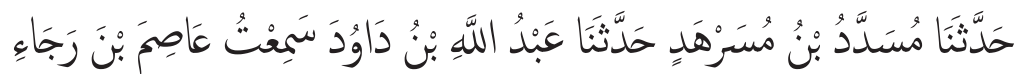

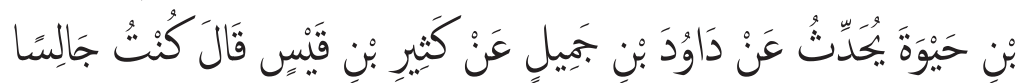

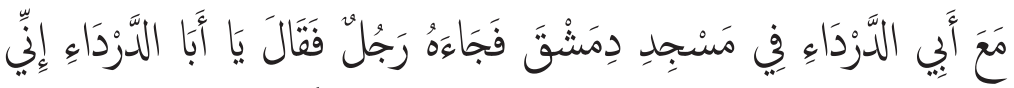

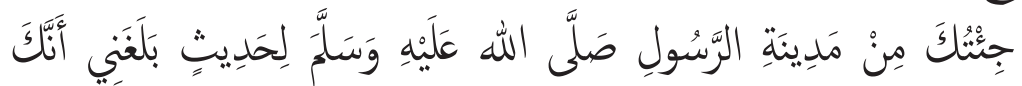

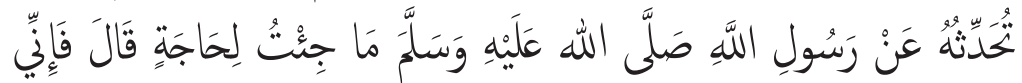

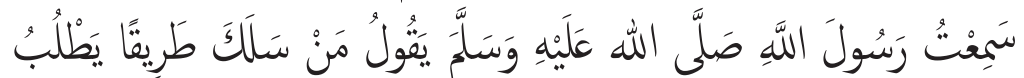

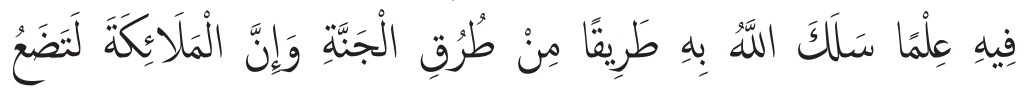

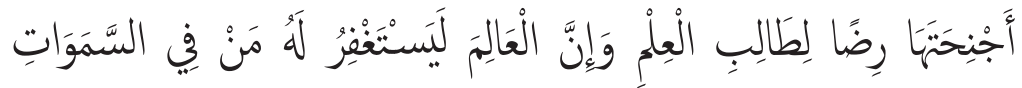

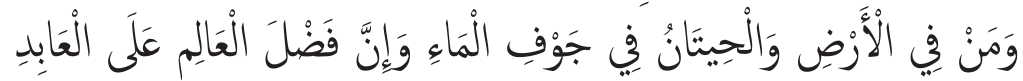

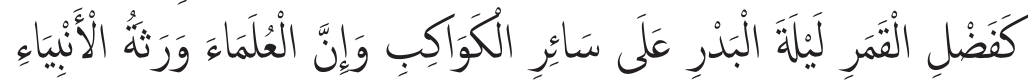

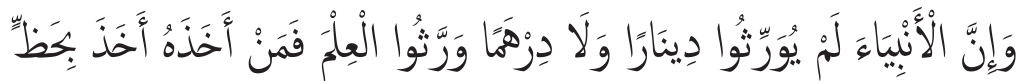

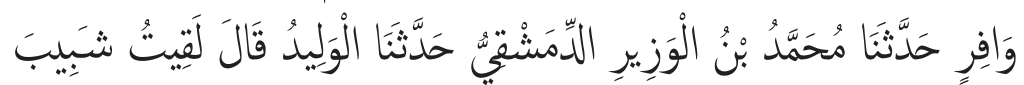

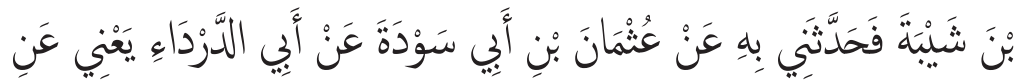

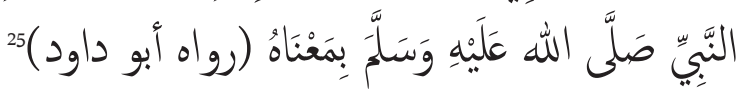

${ }^{24}$ Abu Dawud Sulaiman Ibn al-Asy’a£ al-Azdiy, Sunan Abu Dawud, Juz III (Indonesia: Maktabah Dahlan, t.th.), 317.

${ }^{25}$ Ibid., 320. 


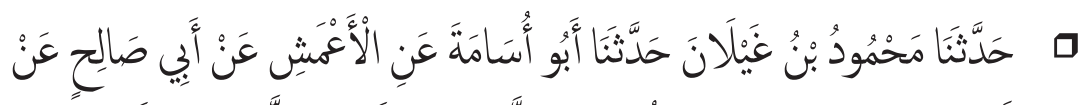

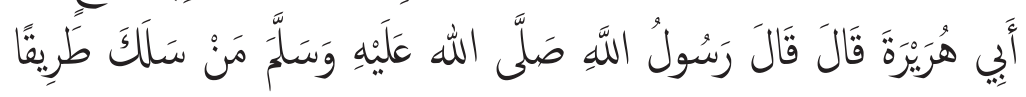

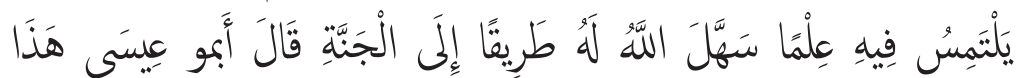

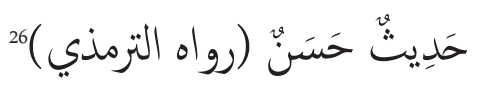

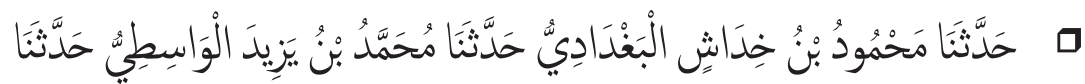

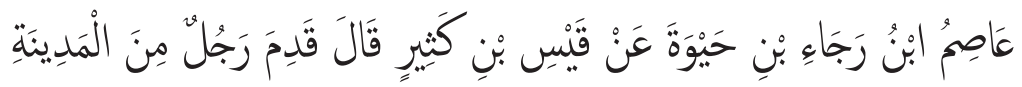

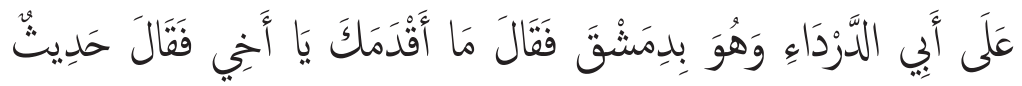

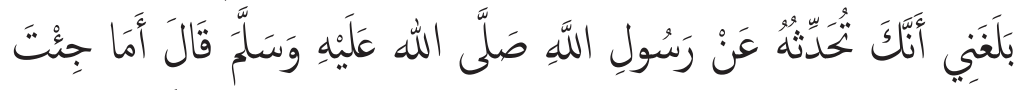

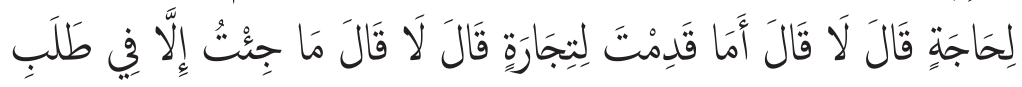

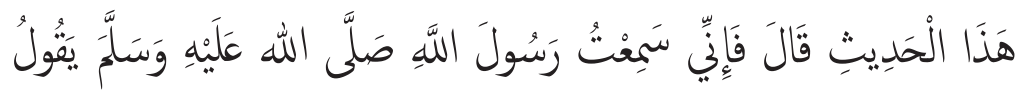

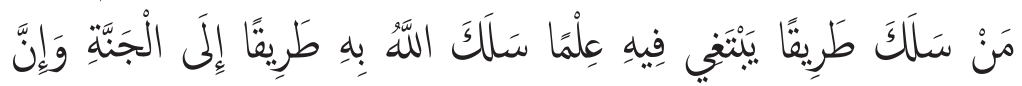

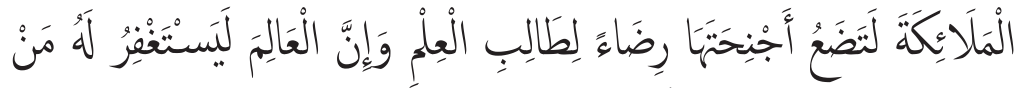

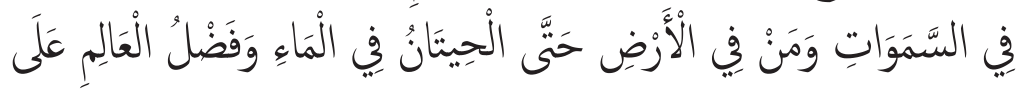

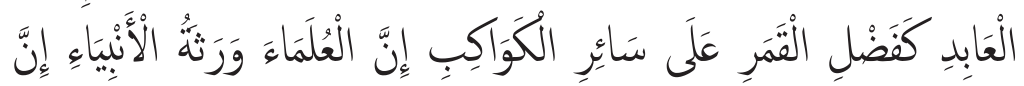

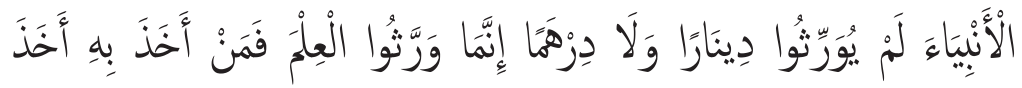

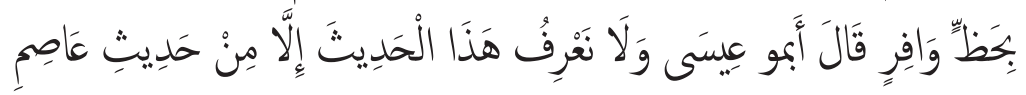

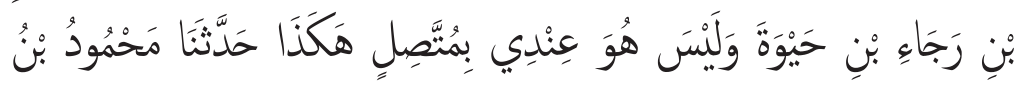

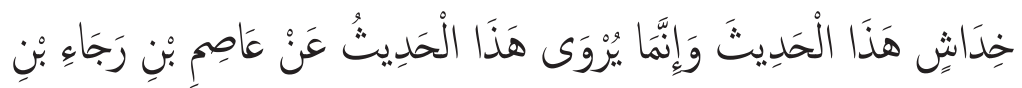

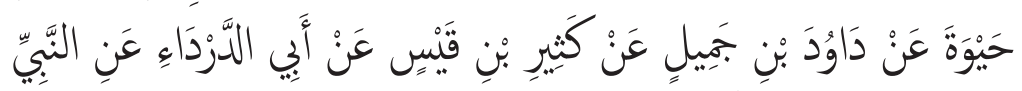

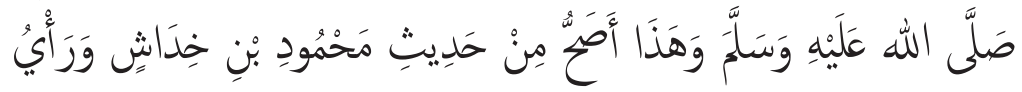

\footnotetext{
${ }^{26}$ Abu Isa Muhammad ibn Isa al-Turmuziy, Sunan al-Turmuzi, Juz III (Beirut: Dar al-Fikr, t.t.), 276.
} 


\section{مُحَمَّدِدِنِ إِنْمَعِيلَ هَذَا أَصَحُ (رواه الترمذي)}

4. Hadis tentang konsep fitrah dalam dunia pendidikan, susunan sanad dan matan-nya adalah sebagai berikut :

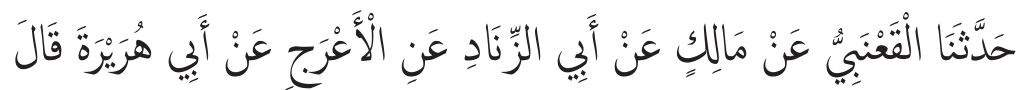

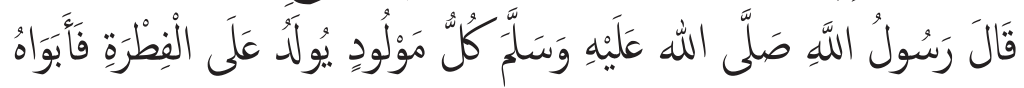

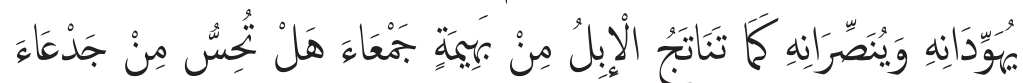

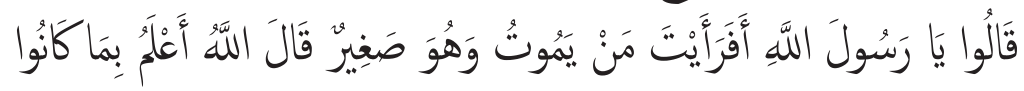

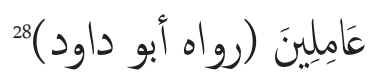

5. Hadis tentang pendidikan shalat bagi anak sejak umur tujuh tahun, susunan sanad dan matan-nya adalah sebagai berikut:

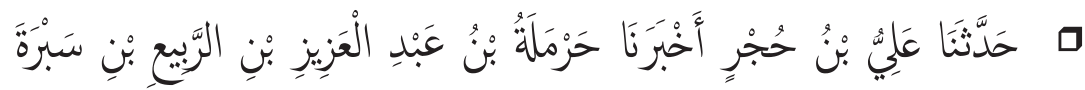

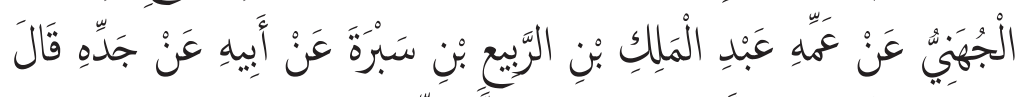

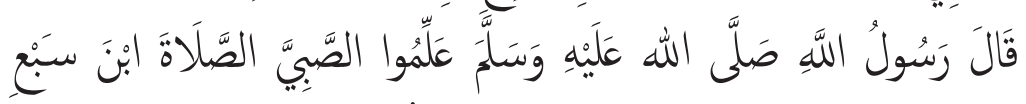

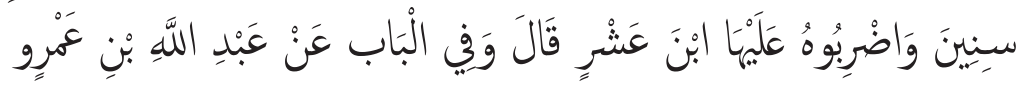

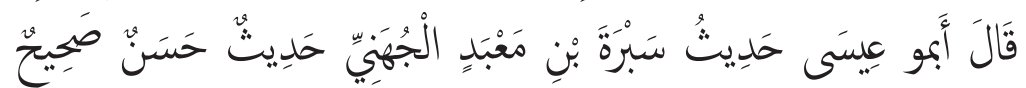

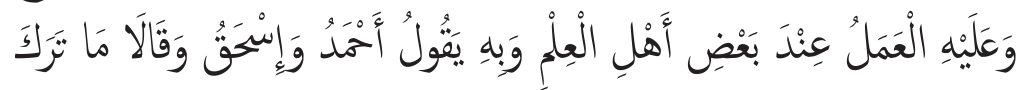

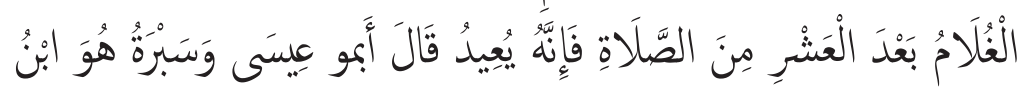

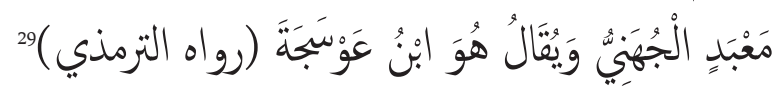

\footnotetext{
${ }^{27}$ Ibid., 301.
}

${ }^{28}$ Abu Dawud Sulaiman al-Sijistani, Sunan Abu Dawud, kitab al-Sunnah, Hadis ke-4091. CD-Rom Hadis.

${ }^{29}$ Abu Isa Muhammad ibn Isa al-Turmuziy, Sunan al-Turmuziy, kitab al-Shalat, Hadis ke-272. CD-Rom Hadis. 


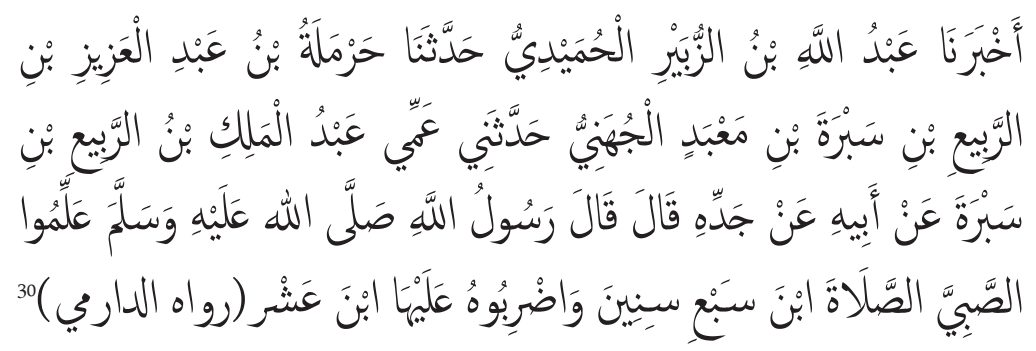

Setelah men-takhrij dan mengklasifikasi Hadis-Hadis tentang pendidikan, perlu sedikit disinggung tentang naqd al-Hadis, yakni kritik tentang kualitas Hadis-Hadis tersebut. Dalam hal ini, Hadis-Hadis yang telah dikutip sebelumnya menurut catatan dalam kitab-kitab Hadis, dan kitab syarah-nya, serta sumber lain yang dapat dipertanggungjawabkan, dinyatakan bahwa semuanya berkualitas shahih.

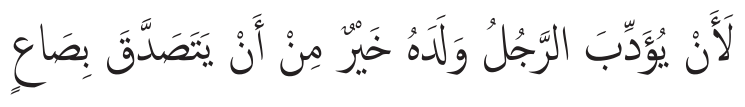

Bagi orang tua yang mendidik anaknya dengan baik, sungguh lebih utama dibandingkan bila ia bersedekah se-sha'

Istilah pendidikan dalam Hadis di atas, terdapat pada kata يُوَدِّبَ . Jika kata ini disinonimkan dengan makna al-tarbiyah, maka yang digunakan istilah al-ta'dìb yang akar katanya adalah addaba-yu'addibuta'dīban yang berarti memberi adab, atau perilaku. ${ }^{31}$ Kata ini memang tidak ditemukan dalam al-Qur'an yang mengacu pada makna pendidikan, tetapi dalam Hadis kata ini banyak disebutkan di samping dalam matan Hadis tersebut. Antara lain Nabi Saw. menyatakan ألّّنى الهّ (Allah Swt. telah menanamkan adab/pendidikan pada diriku). Lebih lanjut, Naquib al-Attās menyatakan bahwa, istilah pendidikan dengan kata

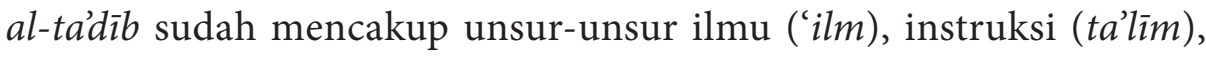

\footnotetext{
${ }^{30}$ Sunan al-Darimi, Kitab al-Shalat, Hadis ke-1395. CD-Rom Hadis.

${ }^{31}$ Luwis Ma'lūf, Al-Munjid fiy al-Lugah (Beirut: Dar al-Masyriq, 1973), 18.

${ }^{32}$ Abū 'Abd. Allah Muhammad ibn Ismā'il ibn Ibrahim ibn al-Mugirah ibn alBukhāri, Sahih al-Bukhariy, Kitab al-'Ilm, Hadis Nomor 1211. CD-Rom Hadis.
} 
dan pembinaan yang baik (tarbiyah).$^{33}$ Kemudian dalam konseptualnya, kata $t^{\prime}{ }^{\prime} i \bar{b} b$ sudah mencakup unsur-unsur pengetahuan, pengajaran, dan pengasuhan yang baik. ${ }^{34}$ Dalam perspektif ini, Nurcholish Madjid menyatakan bahwa perkataan $a l$-ta'dì $b$ dalam arti adab juga digunakan dalam konteks yang merujuk pada kajian kesusastraaan dan etika profesional dan kemasyarakatan. ${ }^{35} \mathrm{Al}$-Qur'an menegaskan bahwa contoh ideal bagi orang yang beradab adalah Nabi Saw. ${ }^{36}$ Karena itu, ta'dì $b$ dalam arti pendidikan adalah mengacu pada dimensi akhlak.

Dalam Hadis itu, juga disinggung bahwa salah satu dimensi akhlak yang mulia adalah bersedekah, dan merupakan salah satu amal yang terpuji dalam Islam. Bersedekah dapat meringankan beban sesama muslim, sehingga hal tersebut dapat memberikan kegembiraan kepadanya. Dengan bersedekah, maka sangat banyak hal-hal positif yang dapat dilaksanakan. Namun demikian, menanamkan pendidikan ternyata lebih jauh penting dibanding dengan bersedekah. Anak yang terdidik dengan baik akan menjadi anak yang beriman, berakhlak, dan berbudaya. Kapasitas anak yang dilahirkan oleh buah pendidikan ini, terbukti dapat melahirkan anak yang dapat memberikan sedekah yang lebih banyak dibanding sedekah yang diberikan orang tuanya sebanyak satu sha' saja.

Sebaliknya, anak yang tidak terdidik dengan baik dapat saja menghilangkan sedekah yang pernah diberikan kepada seseorang dengan menyakiti hatinya atau bahkan dapat saja merobohkan bangunan yang dibangun dengan sumbangan yang diberikan oleh ayahnya.

Yang menjadi persoalan berikutnya adalah pendidikan yang bagaimana yang diinginkan oleh hadis tadi? Diyakini bahwa pendid-

${ }^{33}$ Demikian yang dikemukakan al-Attas dalam Wan Mohd. Nor Wan Daud, The Educational Philosophy and Practice of Syed Muhammad Naquib al-Attas (Filsafat dan Praktik Pendidikan Islam Syed M. Naquib al-Attas), terj. Hamid Fahmi, et.al. Cet. I (Bandung: Mizan, 2003), 174-175, 185, dan 318.

${ }^{34}$ Ibid., 75.

${ }^{35}$ Nurcholish Madjid, Khazanah Intelektual Islam. Cet. III (Jakarta: Bulan Bintang, 1994), 3.

${ }^{36}$ Q.S. al-Ahzāb ([33]: 21). 
ikan yang diinginkan oleh Hadis tersebut adalah adalah pendidikan Islam. Orang Islam menyakini bahwa kehidupan tidak dapat diserahkan seluruhnya kepada kemampuan akal manusia secara pribadi atau manusia dalam arti keseluruhan manusia. Pandangan orang Islam bertolah belakang dari humanisme yang mengajarkan bahwa akal manusia telah mencukupi untuk mengatur dunia dan kehidupan manusia, dan karena itu agama tidak diperlukan. ${ }^{37}$ Dengan demikian, pendidikan yang diiginkan Nabi Saw. sebagaimana dalam Hadis tersebut, bukanlah pendidikan yang menanamkan faham humanisme dan pendapat lain yang tidak sejalan dengan ajaran Islam.

\section{Urgensi Mengajarkan Ilmu melalui Pendidikan}

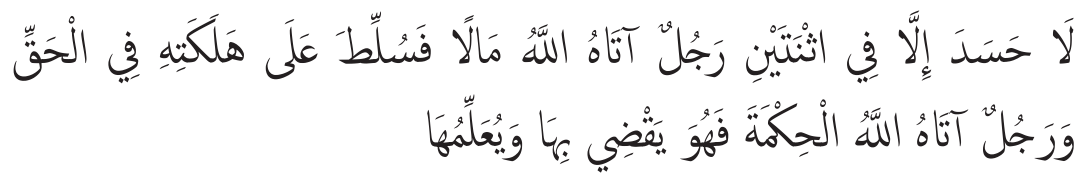

Tidak boleh mengingkan kepunyaan lain orang melainkan dua macam. Orang yang diberi oleh Allah kekayaan, maka dipergunakan untuk membela haq (kebenaran) dan orang yang diberi oleh Allah hikmah (ilmu pengetahuan) maka diajarkannya kepada orang lain.

Hadis di atas mengemukakan bahwa al-hikmah bermakna ilmu pengetahuan dalam yang diperoleh dalam proses pendidikan. Istilah alhikmah yang bentuk pluralnya adalah al-hikam secara leksikal berarti al-falsafah (kebijaksanaan); al-'adl (keadilan); al-hilm (penyantun); dan al-'ilm (pengetahuan). ${ }^{38}$ Karena itu, batasan istilah al-hikmah dengan al'ilmu secara harfiyah adalah sama (mutaradifani). Lebih lanjut, Ibn Hajar al-Asqalani dalam men-syarah Hadis tersebut, beliau menyatakan bahwa

\footnotetext{
${ }^{37}$ Ahmad Tafsir, Ilmu Pendidikan dalam Perspektif Islam (Bandung: Remaja Rosda Karya, 1994), 21.

${ }^{38}$ Ma'luf, Al-Munjid fiy al-Lugah, 146.
} 
39 (yang dimaksud al-hikmah adalah segala yang terhindar dari kebodohan dan segala yang terhalang dari keburukan). Dari sini, dapatlah dipahami bahwa al-hikmah adalah lawan dari al-jahl (kebodohan) dan orang yang berilmu (al-'alim) juga diterminologikan sebagai lawan dari al-jahil (orang yang bodoh).

Istilah al-hikmah dalam al-Qur'an ${ }^{40}$ juga diartikan sebagai al-fahmu wa al-'ilmu (pemahaman dan pengetahuan) yang berasal dari Allah dan diperoleh setelah berusaha dalam kegiatan dan proses pendidikan. ${ }^{41}$ Dengan demikian, istilah al-hikmah pada Hadis di atas diartikan sebagai ilmu pengetahuan yang dimiliki manusia dan ilmu tersebut bersumber dari Allah. Secara global, Hadis yang dikaji ini menjelaskan bahwa sikap iri hati (hasad) dibolehkan dalam agama, tetapi hanya dalam dua hal. Pertama, iri hati kepada seseorang yang menggunakan hartanya di jalan kebenaran; dan kedua, iri hati kepada seseorang yang mengajarkan ilmunya kepada orang lain. Jadi, istilah hasada pada awal matan Hadis tersebut mengandung arti al-gibah (iri yang positif).

Kaitannya dengan itu, Mushtafa Muhammad 'Imarah menyatakan bahwa la hasada dalam Hadis tersebut bermakna:

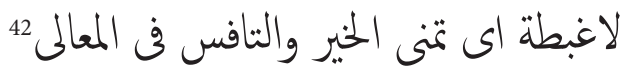

artinya, tidak dilarang untuk iri hati pada cita-cita yang positif dan tidak dilarang pula iri hati untuk berlomba-lomba melakukan amal kebajikan. Lebih lanjut, al-Asqalani juga menyatakan bahwa la hasada dalam Hadis tersebut adalah:

${ }^{39}$ Ahmad bin 'Ali bin Hajar al-Asqlani, Fath al-Bary Sayrh Shahih al-Bukhari, Jilid I (Beirut: Dar al-Manar, 1990), 205.

${ }^{40}$ Q.S. Luqman ([31]: 12).

${ }^{41}$ Abu al-Fida Mujhammad bin Isma'il Ibn Katsir, Tafsir al-Qur'an al-'Azhim, Jilid III (Semarang: Toha Putra, t.t.), 444.

${ }^{42}$ Mushtafa Muhammad 'Imarah, Syarh Riyad al-Shalihin (Beirut: Dar al-Tsaqafah al-Islamiyah, t.t.), 612 . 


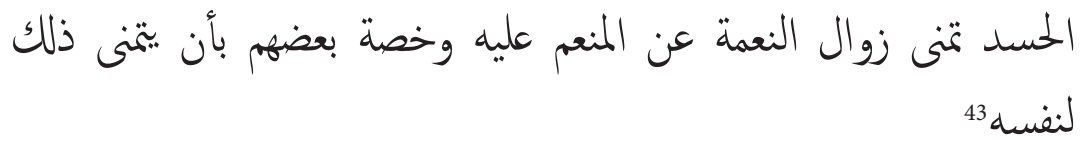

yakni, al-hasad merupakan keinginan seseorang untuk mendapatkan nikmat seperti yang dimiliki oleh orang lain, tanpa diiringi dengan keinginan agar kenikmatan itu lenyap dari orang lain dan dari dirinya sendiri. Itu berarti bahwa upaya untuk memperoleh ilmu dengan cara mengaktifkan diri dalam dunia pendidikan adalah sesuatu yang sangat urgen dan signifikan.

Adapun potongan matan Hadis di atas yang menyatakan:

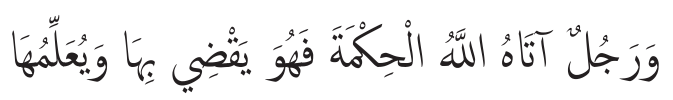

yang mengindikasikan bahwa seseorang yang telah diberi hikmah (dari Allah) hendaklah orang tersebut mengajarkannya kepada orang lain. Tentu saja, al-hikmah yang dimaksud dalam hadis ini adalah adalah ilmu-ilmu al-din (ilmu agama). Jadi, ilmu agama merupakan karunia Allah yang amat urgen bagi manusia, maka ilmu tersebut urgen pula untuk disampaikan (diajarkan) kepada orang lain. Dengan demikian, makna ilmu pengetahuan yang terinterpretasi dalam Hadis yang dikaji ini mencakup kriteria mahmudah (terpuji) dan harus ditransfer kepada orang lain.

\section{Imbalan Bagi Penuntut Ilmu dalam Pendidikan}

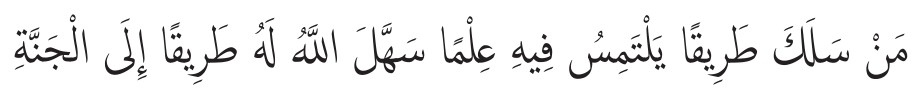

Siapa yang berjalan di suatu jalan menuntut ilmu pengetahuan, Allah akan memudahkan baginya jalan ke surga.

\footnotetext{
${ }^{43}$ Uraian lebih lanjut, lihat al-Asqalani, Fath al-Bary, 204.
} 
Hadis lain yang semakna adalah:

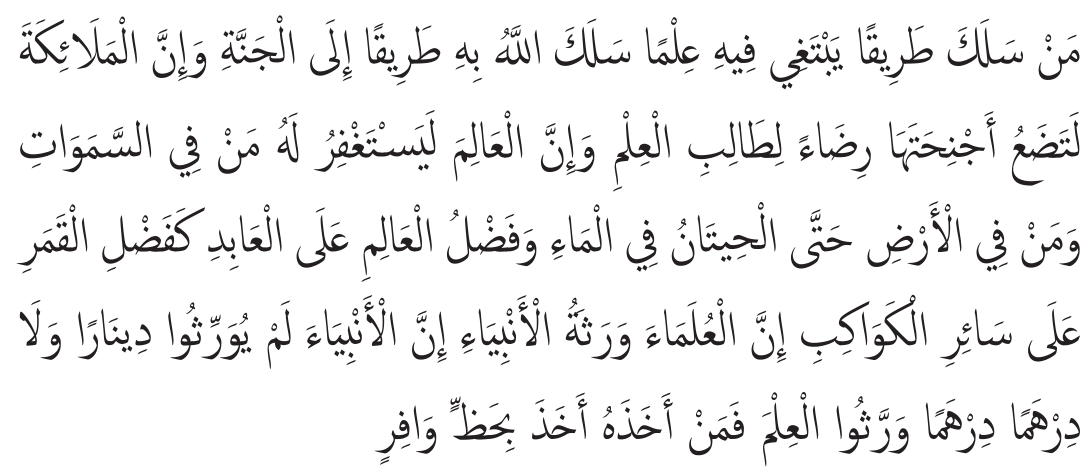

Siapa yang melalui suatu jalan untuk menuntut ilmu, Allah akan memudahkan baginya jalan ke syurga; dan para Malaikat selalu melatakkan sayapnya menaungi para pelajar karena senang dengan perbuatan mereka; dan seorang alim dimintakan ampun oleh penduduk langit dan bumi dan ikan-ikan di dalam air. Kelebihan seorang alim atas orang ibadat bagiakan kelebihan sinar bulan atas lain-lain bintang. Sesungguhnya ulama sebagai waris dari nabi-nabi. Sesungguhnya Nabi tidak mewariskan uang dinar atau dirham, hanya mereka mewariskan ilmu agama, maka siapa yang telah mendapatkannya berarti telah mengambil bahagian yang besar.

Kedua Hadis di atas mengisyaratkan bahwa balasan pahala bagi mereka yang menuntut ilmu dalam proses pendidikan adalah surga. Menurut al-'Abadi, surga yang dimaksud di sini adalah kebahagiaan dunia dan akhirat. Menurutnya, di dunia mereka akan diangkat derajatnya. Dalam QS. al-Mujadalah ([58]: 11), Allah berfirman:

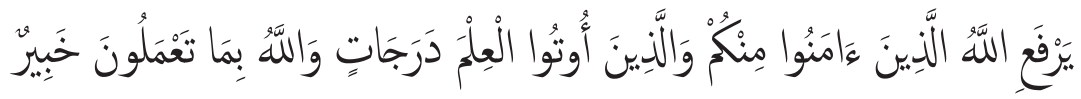

Allah akan meninggikan orang-orang yang beriman di antaramu dan orang-orang yang diberi ilmu pengetahuan beberapa derajat. Dan Allah Maha Mengetahui apa yang kamu kerjakan. 
Di samping orang yang menuntut ilmu diangkat derajatnya oleh Allah, maka di akhirat kelak mereka juga akan merasakan kenikmatan yang hakiki dengan menetapnya di surga. Kebahagiaan surga tersebut ditujukan bagi mereka yang menuntut ilmu (thalib al-'ilm) dan yang mengamalkan ilmunya ('amil al-'ilm) atau yang mengajarkan ilmunya kepada orang lain. ${ }^{44}$ Karena kedudukan mulia yang diraih oleh Nabi Saw., terwariskan kepada ahli ilmu (penuntut ilmu), maka sangat wajar bilamana mereka memperoleh pahala berupa surga, yakni kemuliaan pada sisi Allah di dunia ini dan di akhirat kelak. Pada sisi lain, kemuliaan berupa derajat yang tinggi di sisi Allah yang diperoleh para penuntut ilmu tersebut melalui kegiatan pendidikan (menurut Hadis), mereka juga senantiasa dilindungi oleh malaikat, termasuk semua penghuni alam ini mendoakannya, karena mereka yang menuntut ilmu tersebut lebih mulia dan lebih baik posisinya bila dibandingkan dengan orang yang beribadah, sebagaimana indahnya bulan di atas bintang-bintang gemerlap.

Hadis di atas juga mengisyaratkan bahwa sebelum bertingkah laku dan beribadah hendaknya yang diperdalam dalam proses pendidikan adalah ilmu pengetahuan tentang agama terlebih dahulu. Tanpa dasar ilmu agama, maka ibadah yang dijalankan mungkin saja salah atau tidak sesuai dengan amalan Nabi Saw. Pada sisi lain, Hadis tersebut, juga menegaskan bahwa para ahli ilmu itu adalah pewaris nabi dan diketahui bahwa Nabi Saw. adalah hamba Allah yang paling mulia kedudukannya.

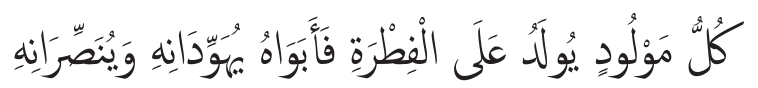

Setiap anak yang dilahirkan dalam keadaan fitrah, maka orang tualah yang akan (mendidiknya) menjadi Yahudi dan atau Nasrani.

Walaupun Hadis di atas, tidak menggunakan kata tarbiyah, ta'lim, ta'dib, ilmu, hikmah, dan yang semakna dengannya, namun Hadis tersebut sering kali ditemukan dalam buku-buku pendidikan Islam. Konteks

\footnotetext{
${ }^{44}$ Uraian lebih lanjut, lihat Abu al-Thayyib Muhammad Syams al-Haq al-'Azim, 'Aun al-Ma'bb Syarh Sunan Abu Dawud. Juz VII (t.t.: al-Maktabah al-Salafiyah, 1979), 51.
} 
Hadis tersebut relevan dengan Q.S. al-Rum ([30]: 30) yang menggunakan kata fitratallahi, yang mengandung interpretasi bahwa manusia diciptakan oleh Allah mempunyai naluri beragama, yaitu agama tauhid. ${ }^{45}$ Potensi fitrah Allah pada diri manusia ini menyebabkannya selalu mencari yang dipandang sebagai realitas mutlak (ultimate reality), dengan cara mengekspresikannya dalam bentuk sikap, cara berpikir dan bertingkah laku. Dengan sikap inilah sehingga manusia juga disebut sebagai homo educandum (makhluk yang dapat didik) dan homo education (makhluk pendidik), karena pendidikan baginya adalah suatu keharusan guna mewujudkan kualitas dan integritas kepribadian yang utuh.

Posisi manusia sebagai homo religious dan homo educandum serta homo education sebagaimana disebutkan di atas, mengindikasikan bahwa sikap keberagamaan manusia dapat diarahkan melalui proses pendidikan dengan memandang fitrah sebagai objek yang harus dikembangkan dan disempurnakan, dengan cara membimbing dan mengasuhnya agar dapat memahami, menghayati, dan mengamalkan ajaran-ajaran keagamaan (Islam) secara universal. Dalam hal ini, al-Qur'an maupun Hadis meskipun tidak secara eksplisit membicarakan tentang konsep dasar keberagamaan, tetapi secara implisit dari konteks ayat maupun Hadis terdapat petunjuk yang mengarah tentang pendidikan keberagamaan.

Hakikat fitrah keimanan sebagai petunjuk bagi orang tua agar lebih eksis mengarahkan pendidikan anak menuju pada fitrah yang dimiliki oleh anak tersebut secara bijaksana di bawah sejak lahir. Di samping itu, Hadis Nabi Saw. tersebut mengandung implikasi bahwa fitrah merupakan suatu pembawaan setiap manusia sejak lahir, dan mengandung nilai-nilai pendidikan religius dan keberlakuannya mutlak.

Di dalam fitrah mengandung pengertian baik-buruk, benar-salah, indah-jelek dan seterusnya. Pelestarian fitrah ini ditempuh lewat pemeliharaan sejak awal (preventif) atau mengembangkan kebaikan setelah ia mengalami penyimpangan (kuratif). ${ }^{46}$ Fitrah yang dimiliki itu sangat

${ }^{45}$ Lihat interpretasi yang dikemukakan oleh al-Raghib al-Ashfahani, Mufradat Alfadz al-Qur'an, Cet. I (Beirut: Dar al-Syamiyah, 1992), 640.

${ }^{46}$ Mudhor Ahmad, Manusia dan Kebenaran (Surabaya: Usaha Nasional, 1989), 
besar dipengaruhi oleh lingkungan, dalam arti bahwa fitrah tidak dapat berkembang tanpa adanya pengaruh positif dari lingkungannya yang mungkin dapat dimodifikasi atau dapat diubah secara drastis bila lingkungan itu tidak memungkinkan untuk menjadi fitrah itu lebih baik. Faktor-faktor yang bergabung dengan fitrah dan sifat dasarnya bergantung pada sejauhmana interaksi dengan fitrah itu berperan.

Pada sisi lain, tentu saja fitrah atau dalam hal ini sikap keberagamaan yang dibawa oleh setiap manusia sejak kecil, pada perkembangannya akan mengalami tingkatan-tingkatan yang bervariasi sesuai dinamika dan faktor-faktor yang mempengaruhinya. Faktor pertama yang mempengaruhi tingkat keberagamaan adalah pengaruh pendidikan dalam lingkungan keluarga, sebagai unit pertama dan institusi pertama anak dipelihara, dibesarkan, dan dididik. Lingkungan keluarga di sini (orang tua) memberikan peranan yang sangat berarti dalam proses pendidikan keberagamaan anak, sebab di lingkungan ini anak menerima sejumlah nilai dan norma yang ditanamkan sejak awal kepadanya. Kaitannya dengan itu, Mappanganro menyatakan bahwa pada masa-masa tersebut keimanan anak belum merupakan suatu keyakinan sebagai hasil pemikiran yang objektif, tetapi lebih merupakan bagian dari kehidupan alam perasaan yang berhubungan erat dengan kebutuhan jiwanya akan kasih sayang, rasa aman, dan kenikmatan jasmaniah. Peribadatan anak pada masa ini masih merupakan tiruan dan kebiasaan yang kurang dihayati. ${ }^{47}$ Peniruan sangat penting dalam kehidupan anak, mulai dari bahasa, mode, adat istiadat dan sebagainya. Hampir semua kehidupan anak berpangkal pada proses peniruan. Misalnya saja, apabila anak-anak itu melihat orang tuannya shalat, maka mereka juga mencoba untuk mengikutinya.

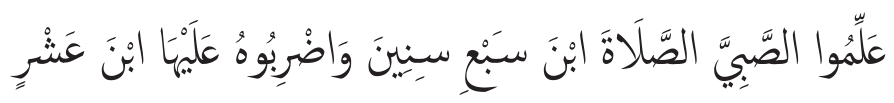

31-32.

${ }^{47}$ Mappanganro, “Masa Kanak-Kanak dan Perkembangan Rasa Keagamaan,” Warta Alauddin, IAIN Alauddin, No. 66 Tahun XII (1993), 16. 
Ajarkanlah anak (mu) untuk shalat sejak umur tujuh tahun dan pukullah mereka (ketika meninggalkan shalat) dalam umur 10 tahun.

Shalat adalah tiang agama, dan karena itulah maka perintah untuk mendidik anak dilakukan sejak dini, yakni sejak anak berusia tujuh tahun. Pendidikan shalat dalam usia dini, lebih awal dimulai oleh usaha orang mendidik anaknya dalam bentuk hadhana. Hal ini seiring dengan fase perkembangan anak, dan ketika ia mulai memiliki potensi-potensi biologis, pedagogis, mulailah diperlukan adanya pembinaan, pelatihan, bimbingan, pengajaran, dan pendidikan yang disebut al-hadhānah.

Hadhanah merupakan hak bagi anak-anak yang masih kecil, karena ia membutuhkan pengawasan, penjagaan, pelaksana urusannya dan orang yang mendidiknya. Pendidikan yang yang paling penting ialah pendidikan anak kecil dalam pangkuan ibu bapaknya. Karena dengan pengawasan dan perlakuan mereka kepadanya secara baik akan dapat menumbuhkan jasmani dan akalnya, membersihkan jiwanya serta mempersiapkan diri anak menghadapi kehidupannya di masa datang. ${ }^{4}$ Proses pembinaan spiritual anak lebih efektif lagi bila dilakukan sejak dalam usia dini sudah dilatih untuk melaksanakan ibadah. Kemudian pada umur tujuh tahun sebagaimana dalam Hadis di atas, hendaknya mereka diperintahkan untuk mendirikan shalat secara kontinyu. Ketika mereka mencapai umur sepuluh tahun dan ketika itu pula mereka meninggalkan shalat, maka hendaklah diberi sanksi fisik berupa pukulan.

Dari Hadis tersebut dapat dipahami bahwa di samping adanya perintah mendidik dan membiasakan anak-anak untuk mengerjakan shalat, juga ada perintah untuk memisahkan anak-anak dari tempat tidurnya. Maksudnya, sejak usia dini anak-anak tersebut harus berpisah tempat tidur dengan orang tuanya dan berpisah tempat tidur dengan saudarasaudaranya yang berlainan jenis kelamin. Hal ini dikarenakan pada fase ini, sang anak mulai aktif dan mampu memfungsikan potensi-potensi

\footnotetext{
${ }^{48}$ Sayyid Sabiq, Fiqh al-Sunnah (Fikih Sunnah) terj. Moh. Thalib, Jilid VIII, Cet. VII (Bandung: PT. Al-Ma’arif, 1990), 161-162.
} 
indranya, ia sudah mulai mengenal mana yang wajar dan yang tidak wajar, mana yang negatif dan yang positif.

Pendidikan yang startegis bagi anak sejak dini di lingkungan rumah tangga, merupakan sesuatu yang esensial dalam menjaga fitrahnya, dan dalam lingkungan itu pula anak telah memperoleh percikan sifat-sifat kesempurnaan Ilahi. ${ }^{49}$ Lebih lanjut, tentang pentingnya pendidikan anak sejak kecil sebab mengacu pada pernyataan:

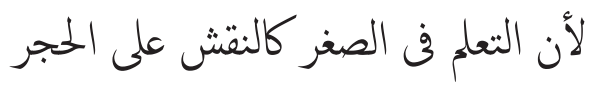

Karena pengajaran di waktu kecil bagaikan mengukir di atas batu. ${ }^{50}$

Ini berarti bahwa jika seseorang yang sejak kecilnya diajarkan dan ditanamkan sifat-sifat ketuhanan, maka sifat-sifat itu berbekas sampai masa dewasa dan sulit terhapus sebagaimana susahnya terhapus tulisan di batu.

\section{Penutup}

Dari uraian-uraian yang telah dikemukakan dapat dirumuskan bahwa pendidikan sangat penting umat manusia. Pendidikan yang dimaksud di sini adalah tarbiyah, yakni proses pembentukan individu berdasarkan ajaran-ajaran Islam. Melalui proses pendidikan itu, individu dibentuk agar dapat mencapai derajat yang tinggi dan sempurna (insan kamil). Hadis-Hadis tentang pendidikan sangat banyak jumlahnya, dan terdapat dalam al-Kutub al-Tis'ah. Hadis-Hadis tentang pendidikan itu, pada dasarnya dapat terklasifikasi dalam lima sub tema, yakni (1) Hadis tentang keutamaan mendidik anak. Dalam Hadis ini, ditemukan syarah bahwa mendidik anak lebih utama dan lebih mulia daripada bersedekah; (2) Hadis tentang urgensi mengajarkan ilmu melalui pendidikan. Dalam Hadis dipahami bahwa mengajarkan ilmu kepada orang lain sangat penting dan menjadi kewajiban bagi setiap muslim; (3) Hadis tentang

${ }^{49}$ Lihat lebih lanjut, Achmadi, Ideologi Pendidikan Islam, Cet. I (Yogyakarta: Pustaka Pelajar, 2005), 44.

${ }^{50}$ Ahmad Fu’ad al-Ahwāniy, al-Tarbiyah fill Islam (Mesir: Dār al-Ma’arif, t.t.), 242. 
balasan yang diperoleh bagi penuntut ilmu dalam pendidikan. Dalam Hadis ini dipahami bahwa seseorang yang menuntut ilmu dalam dunia pendidikan akan mendapatkan balasan pahala berupa surga; (3) Hadis tentang konsep fitrah dalam dunia pendidikan. Dalam Hadis ini dipahami bahwa fitrah seorang anak harus dikembangkan melalui proses pendidikan yang Islami; (5) Hadis tentang pendidikan shalat bagi anak. Dalam Hadis ini dipahami bahwa kewajiban orangtua adalah mendidik anak-anaknya untuk melaksanakan ibadah shalat sejak dini, yakni sejak umur tujuh tahun. Hadis-Hadis yang telah diklasifikasi, dan di-syarah secara maudhui dalam tulisan ini berkualitas shahih. Karena itu, kajian penulis di sini berimplikasi pada pentingnya pengamalan Hadis-Hadis tentang pendidikan dalam kehidupan.

\section{Daitar Pustaka}

Al-Abadi, Abu al-Thayyib Muhammad Syams al-Haq al-'Azim. 'Aun al-Ma'bb Syarh Sunan Abu Dawud, Juz VII. t.tt.: al-Maktabah alSalafiyah, 1979.

Al-Abrāsy, Muhammad Athiyah. Rūh al-Tarbiyah wa al-Ta'līm. t.tt.: Isā al-Bābī al-Halab, t.t.

Achmadi. Ideologi Pendidikan Islam. Cet. I. Yogyakarta: Pustaka Pelajar, 2005.

Ahmad, H. Arifuddin. Prof. Dr. H. M. Syuhudi Ismail; Paradigma Baru Memahami Hadis Nabi. Cet. I. Jakarta: Intimedia dan Insan Cemerlang, 2003.

Ahmad, Mudhor. Manusia dan Kebenaran. Surabaya: Usaha Nasional, 1989.

Al-Ahwāniy, Ahmad Fu’ad. al-Tarbiyah fìl Islam. Mesir: Dār al-Ma’arif, t.t. 
Al-Ashfahani, al-Raghib. Mufradat Alfadz al-Qur'an. Cet. I. Beirut: Dar al-Syamiyah, 1992.

Al-Asqlani, Ahmad bin 'Ali bin Hajar. Fath al-Bary Sayrh Shahih alBukhari, Jilid I. Beirut: Dar al-Manar, 1990.

Al-Attās, Muhammad Naquib. Aims and Objective of Islamic Education. Jeddah: King Abd. al-Azīz, 1999.

Al-Azdiy, Abu Dawud Sulaiman Ibn al-Asy'as. Sunan Abu Dawud. Juz III. Indonesia: Maktabah Dahlan, t.t.

Ibn Hanbal, Abu Abdullah Ahmad. Musnad Ahmad bin Hanbal. CD-Rom Hadis Musnad al-Bashriyyin.

Ibn Katsir, Abu al-Fida Mujhammad bin Isma'il. Tafsir al-Qur'an alAzhim, Jilid III. Semarang: Toha Putra, t.t.

Imarah, Mushtafa Muhammad. Syarh Riyad al-Shalihin. Beirut: Dar alTsaqafah al-Islamiyah, t.t.

Ismail, M. Syuhudi. Kaedah Kesahihan Sanad Hadis. Jakarta: Bulan Bintang, 1988. . Metodologi Penelitian Hadis. Cet. I. Jakarta: Bulan Bintang, 1992.

Ma'lūf, Luwis. Al-Munjid fiy al-Lugah. Beirut: Dar al-Masyriq, 1973.

Madjid, Nurcholish. Khazanah Intelektual Islam. Cet. III. Jakarta: Bulan Bintang, 1994.

Mappanganro. "Masa Kanak-Kanak dan Perkembangan Rasa Keagamaan.” Warta Alauddin. IAIN Alauddin. No. 66, Tahun XII, 1993.

Al-Nahlawy, Abdurrahman. Usul al-Tarbiyah al-Islamiyah wa Asâlibuha (Prinsip-Prinsip dan Metode Pendidikan Islam) terj. Herry Noor Ali. Cet. II. Bandung: IKAPI, 1992.

Al-Qusyairy, Abu al-Hasan Muslim bin al-Hajjaj bin Muslim. Shahih Muslim, Juz I. Bandung: Maktabah Dahlan, t.t.

Sabiq, Sayyid. Fiqh al-Sunnah (Fikih Sunnah) terj. Moh. Thalib. Jilid VIII. Cet. VII. Bandung: PT. Al-Ma'arif, 1990. 
Tafsir, Ahmad. Ilmu Pendidikan dalam Perspektif Islam. Bandung: Remaja Rosda Karya, 1994.

Al-Turmuziy, Abu Isa Muhammad ibn Isa. Sunan al-Turmuziy, Juz III. Beirut: Dar al-Fikr, t.t.

Wan Daud, Wan Mohd. Nor. The Educational Philosophy and Practice of Syed Muhammad Naquib al-Attas (Filsafat dan Praktik Pendidikan Islam Syed M. Naquib al-Attas) terj. Hamid Fahmi, et.al. Cet. I. Bandung: Mizan, 2003.

Wensinck, A. J. Concordance et Indices De Ela Tradition Musulmanne (al-Mu'jam al-Mufahras li Alfaz al-Hadits al-Nabawiyah), terj. Muhammad Fu'ad 'Abd. al-Baqy. Jilid IV. Leiden: E.J.Brill, 1936. . A Handbook of Earli Muhammadan (Miftah Kunuz al-Sunnah), terj. Muhammad Fu'ad 'Abd. al-Baqy. Beirut: Dar Ihya al-Turats al-Arabiy, $1422 \mathrm{H}$. 